\title{
The longitudinal pattern of crustacean (Peracarida, Malacostraca) assemblages in a large south European river: bank reinforcement structures as stepping stones of invasion
}

\author{
Krešimir Žganec ${ }^{1, *}$, Renata Ćuk ${ }^{2}$, Jelena Tomović ${ }^{4}$, Jasna Lajtner ${ }^{3}$, Sanja Gottstein ${ }^{3}$, Simona \\ Kovačević $^{5}$, Sandra Hudina ${ }^{3}$, Andreja Lucić ${ }^{3}$, Martina Mirt ${ }^{6}$, Vladica Simić ${ }^{5}$, Tatjana Simčič ${ }^{7}$ and \\ Momir Paunović ${ }^{4}$ \\ ${ }^{1}$ University of Zadar, Department of Teacher Education Studies in Gospić, 53000 Gospić, Croatia \\ ${ }^{2}$ Hrvatske Vode, Central Water Management Laboratory, Ulica grada Vukovara 220, 10000 Zagreb, Croatia \\ ${ }^{3}$ University of Zagreb, Faculty of Science, Department of Biology, Rooseveltov trg 6, 10000 Zagreb, Croatia \\ ${ }^{4}$ Institute for Biological Research "Siniša Stanković", University of Belgrade, Despota Stefana 142 Blvd, 11000 Belgrade, Serbia \\ ${ }^{5}$ Institute of Biology and Ecology, Faculty of Science, University of Kragujevac, 12 Radoja Domanovica str, 34000 Kragujevac, Serbia \\ ${ }^{6}$ University Clinical Centre Ljubljana, Zaloška 7, 1000 Ljubljana, Slovenia \\ ${ }^{7}$ National Institute of Biology, Večna pot111, 1000 Ljubljana, Slovenia
}

Received: 23 August 2017; Accepted: 26 February 2018

\begin{abstract}
The spread of alien crustaceans has significantly contributed to the homogenization of macroinvertebrate fauna of European freshwaters. However, little is known about alien Peracarida crustaceans of the Sava River, which represents the most important corridor for the spread of invasive species into Dinaric rivers with highly endemic fauna. In this study, we investigated Peracarida (Amphipoda, Isopoda and Mysida) collected during three years (2011, 2012 and 2015) from a total of 61 sites along the entire course of the Sava River. Besides describing the longitudinal pattern of Peracarida assemblages, we tested the hypothesis that bank reinforcement structures facilitate peracarid invasions by comparing densities and assemblages on natural and artificial substrate at 15 sites. In a total, 14 peracarid crustacean species ( 5 native and 9 alien) were recorded. The Upper third of Sava was inhabited by native peracarids only, while the Middle and Lower Sava were dominated by alien species. The invasive amphipods Dikerogammarus haemobaphes, Chelicorophium sowinskyi and Chelicorophium curvispinum, and invasive isopod, Jaera istri, were the most abundant species along the middle course. Densities of alien peracarids in the Middle Sava were the highest and their share in macroinvertebrate assemblages was very variable, while the Lower Sava had the highest number of alien species in low densities. The densities of alien amphipods and isopods were in most cases significantly higher on bank reinforcement structures than on natural substrate. Therefore, artificial stony substrates act as stepping stones of invasion for alien peracarids and largely contribute to their success in large lowland rivers.
\end{abstract}

Keywords: invasive Amphipoda / Isopoda / Mysida / micro-distribution / Sava

\section{Introduction}

Large European rivers have been heavily affected by combinations of anthropogenic factors, among which land-use change, pollution, damming, hydromorphological changes and biological invasions have had the greatest impact (Whitton, 1984; Petts et al., 1993; Tockner et al., 2009; Strayer et al., 2014). Alien species that are usually better adapted to disturbance (e.g. Den Hartog et al., 1992; Karatayev et al.,

\footnotetext{
*Corresponding author: kzganec@unizd.hr
}

2009) have replaced the native fauna of large European rivers and spread through extensive trans-European inland channel networks used for transportation (Bij de Vaate et al., 2002; Leuven et al., 2009). In addition, freshwater introductions are continuously on the rise, both in number of species and pathways (Nunes et al., 2015). The end result of these processes is a high level of biocontamination of most large European rivers (Arbačiauskas et al., 2008). The number of alien and invasive species in European waters is continually increasing, with about 300 exotic freshwater invertebrates and more than 130 fish recorded in pan-European lake and river ecosystems (European Environment Agency, 2012). 
In freshwaters, crustaceans are among the most successful invaders (Holdich and Pöckl, 2007). The biomass, density and lifespan of some crustacean species, as well as their functional roles in ecosystem processes through feeding, bioturbation and burrowing (e.g. Lodge, 1993; Statzner et al., 2003; Bernauer and Jansen, 2006; Van Riel et al., 2006) make them a key component of freshwater ecosystems. Holdich and Pöckl (2007) listed 54 crustaceans, mainly from the superorder Peracarida (Amphipoda, Cumacea, Isopoda, Mysida) and order Decapoda, as invasive alien species in Europe. These groups include some of the most notorious freshwater invaders, such as the amphipods Dikerogammarus villosus (Sowinsky, 1894) and Chelicorophium curvispinum (G.O. Sars, 1895), crayfish Pacifastacus leniusculus (Dana, 1852) and Procambarus clarkii (Girard, 1852), and mysids Hemimysis anomala (G.O. Sars, 1907) and Limnomysis benedeni Czerniavsky, 1882.

Invasive peracarid crustaceans can exhibit substantial negative impacts on native crustaceans (Van den Brink et al., 1993; Jazdzewski et al., 2002; Grabowski et al., 2007) and other macroinvertebrates (Dick and Platvoet, 2000; Bernauer and Jansen, 2006; Boets et al., 2010; Gergs and Rothhaupt, 2015). Moreover, alien peracarids have shown a greater tolerance to severe environmental conditions, especially elevated salinity (Devin and Beisel, 2006; Statzner et al., 2008; Grabowski et al., 2009). Finally, invasive peracarids exhibit relatively high dispersal rates in European rivers, ranging from 14-461 km year ${ }^{-1}$ for amphipods, and 31$185 \mathrm{~km}$ year $^{-1}$ for the isopod Jaera istri Veuille, 1979 (Josens et al., 2005; Leuven et al., 2009). Due to their high abundance, pronounced negative impacts and relatively high dispersal rates, alien and invasive peracarids and decapods have largely contributed to the homogenization of macroinvertebrate assemblages of European freshwater systems.

Despite their immense impacts, surprisingly few studies report on the relative abundance of Peracarida in macroinvertebrate assemblages (e.g. Van den Brink et al., 1993; Van Riel et al., 2006), and studies examining variations of their impact on macroinvertebrate composition and structures in large rivers are scarce (e.g. Hellmann et al., 2017). Furthermore, in most studies of alien Peracarida that have been conducted thus far, the substrate types were either not sampled separately or only artificial stony microhabitats were sampled (e.g. Van den Brink et al., 1993; Josens et al., 2005), and comparisons between the densities or assemblage composition of Peracarida on natural and artificial substrates in large rivers are lacking. This impedes our understanding of invasion processes in freshwaters since the channel morphology of large rivers has drastically changed due to straightening and channelization, removal of large woody debris and the construction of bank reinforcement structures such as ripraps, groynes and embankments. Finally, a very limited number of studies of alien macroinvertebrates in Western Balkan rivers have been performed (Paunović et al., 2005; Zorić et al., 2011; Marković et al., 2015). After the reconstruction of the RhineMain-Danube canal in 1992, the Danube has assumed the role of the southern invasion corridor through which PontoCaspian invaders spread to central and Western Europe (Bij de vaate et al., 2002). Although the Sava River, as the largest tributary of the Danube in terms of discharge, is an important international watercourse, biological invaders along its course have been sporadically studied. Only a few recently published articles have documented the macroinvertebrates of the Middle and Lower Sava (Paunović et al., 2012; Lucić et al., 2015), whereas macroinvertebrate assemblages along the entire course of the Sava were only examined once (Matoničkin et al., 1975), and only two recent studies have documented crustacean (Malacostraca) fauna of the Middle Sava (Žganec et al., 2009; Maguire et al., 2011). The Sava River represents the most important corridor for the spread of invasive species into Dinaric rivers that harbor highly endemic fauna and are of paramount importance for European freshwater biodiversity (Schneider-Jacoby, 2005; Tierno de Figueroa et al., 2013; Žganec et al., 2016). Thus, research into and the monitoring of invasive alien species in the Sava River are urgently required to increase our understanding of potential processes that facilitate further invasions.

The aim of this study was to examine the longitudinal distribution of native and alien Peracarida crustaceans along the entire course of the Sava River and their relative share in macroinvertebrate assemblages, as a measure of the impact of alien peracarids. Records from previous studies were used to assess upstream spread of invasive peracarids. In addition, the impact of anthropogenic hydromorphological changes, i.e. riprap stony bank reinforcement structures or artificial substrate composed of meso-, macro- and megalithal at reaches with finer natural sediment, was examined by comparing the densities and peracarid assemblages on natural and artificial substrates in order to test the hypothesis that bank reinforcement structures facilitate Peracarida invasions.

\section{Materials and methods}

\subsection{Study area - Sava River}

The Sava River is $926 \mathrm{~km}$ long (if considering the longer of two source branches, the Sava Dolinka) (Schwarz, 2016) and is the largest tributary of the Danube in volume (with $1572 \mathrm{~m}^{3} \mathrm{~s}^{-1}$ average annual discharge at its mouth), and the second largest river after the Tisza in terms of catchment area $\left(95793 \mathrm{~km}^{2}\right)$ (Sommerwerk et al., 2009). The Sava begins at the confluence of two headwaters: the Sava Dolinka (source at $870 \mathrm{~m}$ a.s.1.) and Sava Bohinjka (526 m a.s.1.) in the Julian Alps in Slovenia. At its spring area in the Julian Alps, the Sava River flows through narrow river valleys or deep gorges, then passes through more open valleys in Slovenia. In the middle course in Croatia, it meanders along a wide valley, while in its lower course, before it reaches the confluence with the Danube in Belgrade (Serbia) it is $0.3-0.7 \mathrm{~km}$ wide. Based on previous studies (Urbanič, 2008; Paunović et al., 2012; Lucić et al., 2015) and our own data, five major sections of the Sava can be distinguished (Fig. 1): Alpine, Subalpine, Upper, Middle and Lower Sava.

There are ten dams along the Sava in Slovenia (Fig. 1), while the impoundment section of the Iron Gate I dam on the Danube extends $100 \mathrm{~km}$ into the Lower Sava (ICPDR, 2005). Although many towns, factories and power plants along its course still represent sources of point pollution, the severe pollution of the Middle Sava reported in previous studies (Meštrov et al., 1978, 1989) has been reduced, and water quality has significantly improved due to the collapse of industry after the war in the 1990s, and after Zagreb's 


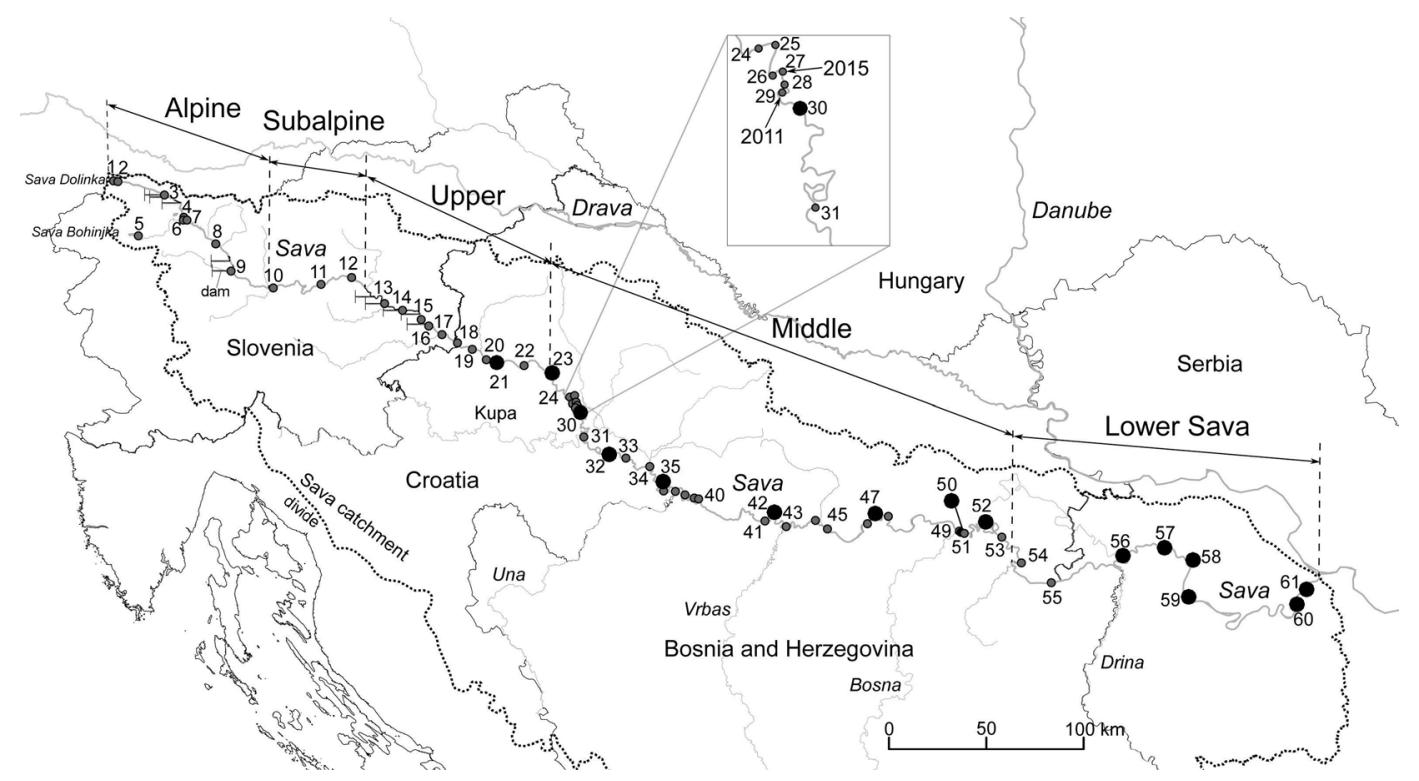

Fig. 1. Sampling sites (61) along the entire course of the Sava River, with five major sections. Inset map shows eight very close sites at the beginning of the Middle Sava section, with two sites marked by arrows where the upstream front of the invasive amphipod Dikerogammarus haemobaphes was detected in 2011 and in 2015. Large black dots represent 15 sites were natural and artificial substrates were sampled separately.

Table 1. Sampling time and methods used at all 61 sites at particular sections of the Sava River. Methods of sampling are indicated by bold, plain text and italic site numbers: bold - quantitative sampling $(10 \times$ natural $+10 \times$ artificial substrate in 2011 and 2012 or $20 \times$ multihabitat-AQEM sampling in 2015), plain - five or ten replicate quantitative samples at different microhabitats, italic - qualitative multihabitat sampling during preliminary field survey in 2011 and 2012 or in 2015.

\begin{tabular}{|c|c|c|c|c|}
\hline Month/Year & Alpine/Subalpine & Upper & Middle & Lower \\
\hline 9/2011 & - & 21 & $29, \mathbf{3 0}, \mathbf{3 5}, \mathbf{4 2}, \mathbf{5 0}$ & $56,57,59,60$ \\
\hline 9/2012 & - & - & $\mathbf{2 3}, 29, \mathbf{3 2}, 40, \mathbf{4 7}, \mathbf{5 2}$ & 58,61 \\
\hline $5 / 2015$ & - & $18,19,20,22$ & $23,31,32,37,43,44$ & - \\
\hline $6 / 2015$ & - & - & $45,46,48,49,51,53,55$ & - \\
\hline
\end{tabular}

wastewater treatment plant was put into operation in 2007 (Ogrinc et al., 2015; Andersen and Žganec, 2016). About twothirds of the Sava is navigable, up to the Kupa confluence in Sisak (rkm 594). However, nowadays the Sava is hardly used for transport, primarily due to a lack of maintenance and investments (Komatina and Grošelj, 2015). Flood protection, navigation, hydropower and urbanization have been the main drivers of morphological alterations of the Sava, of which the most important include longitudinal and cross-section channel changes, and the construction of bank reinforcement structures (mainly stony ripraps), groynes, spikes and embankments.

\subsection{Field sampling and laboratory analyses}

Peracarida crustaceans and other macroinvertebrates were collected during three years $(2011,2012$ and 2015) using hand net (aperture: $25 \times 25 \mathrm{~cm}$, mesh size: $500 \mu \mathrm{m}$ ). Sampling in July 2011 and June 2012 along Croatian and Slovenian section of Sava was preliminary and included either qualitative or quantitative sampling to examine distribution and density of native and alien Peracarida. (Fig. 1, Tab. 1). Sampling campaign conducted at 15 sites (Fig. 1 - black dots) in September 2011 (9 sites) and in September 2012 (6 sites) aimed to test the differences of Peracarida assemblages (composition and density) between natural and artificial substrates: ten replicate quantitative samples were collected from each of two substrate types $(10 \times \mathrm{N}+10 \times \mathrm{A})$. Those sites, located in the Upper (1 site), Middle (8) and Lower (6) Sava, were selected to be approximately evenly spaced along cca. $700 \mathrm{~km}$ long reach of Sava, if both substrate types were close enough and accessible to sampling. Those 15 sites were sampled in September during low water level, which usually occurs in Sava at the end of summer. Each replicate sample 
covered $0.0625 \mathrm{~m}^{2}$ of the river bottom area on a shallow bank. The macroinvertebrate samples were collected from natural substrate at microlocations that had not undergone any change due to channelization and thus corresponded to natural substrata along the assessed river reach. Natural substrate samples were collected from every available substrate type (mainly gravel, sand and mud), taking into consideration the relative contribution to each microhabitat type $(10 \%=1$ sample). On riprap stony artificial substrates (mainly macroand mesolithal) replicate samples were collected on the banks (14 sites) or at the groyne (1 site). Differences between densities at natural and artificial substrate types were examined for eight taxa and two taxon groups. Taxa included seven individual Peracarida species (two native and five alien) and alien Chelicorophium sp. (two Chelicorophium species were grouped together since in most cases unidentified juvenile specimens had the highest share in the total abundance of Chelicorophium), and two taxon groups - native species group and alien species group.

Sampling of macroinvertebrates in 2015 (May-July, Tab. 1) at 21 sites of the Croatian section of the Sava was the part of the project aimed at assessing biocontamination of Croatian large rivers (Žganec et al., 2016; Ćuk et al., unpublished) and included standard multihabitat sampling according to AQEM methodology (AQEM Consortium, 2002). Six of these sites were the same as those sampled in 2011 or 2012. Additionally, the distribution front change of the most notorious amphipod invader Dikerogammarus haemobaphes (Eichwald, 1841) was examined by multihabitat qualitative sampling at four sites at the beginning of Middle Sava in September 2015 (Tab. 1, Fig. 1). Macroinvertebrate samples were preserved on-site in $70 \%$ ethanol. In a total, 465 samples of macroinvertebrates were collected at 61 sites along the entire course of the Sava, from the site $360 \mathrm{~m}$ downstream of the source of Sava Dolinka (site 1), and from the outflow of Sava Bohinjka at Lake Bohinj (site 5) to the last site (61) $10 \mathrm{~km}$ upstream of the confluence with the Danube in Belgrade. Site locations were recorded using a GPS receiver and data were mapped using the Arc-GIS 10.1 program package.

In the laboratory, the macroinvertebrates were separated from the sediment and organic detritus and stored in $70 \%$ ethanol for later identification. Peracarid crustaceans were identified using the following keys: Amphipoda - Cărăusu et al. (1955), Karaman and Pinkster (1977a, b), Pinkster (1993), Eggers and Martens (2001); Isopoda - Argano (1979), Veuille (1979), Mysidacea - Dobson (2012), Wittmann et al. (2016). All other non-peracarid taxa were identified to a higher taxonomic level, order (23), class (10) or phylum (2) at 53 sites (at 8 sites only crustacean fauna was separated and identified).

\subsection{Data analyses}

Generalized linear models (GLMs) were used to test for differences in taxon or taxon group abundance between natural and artificial substrates within each sampling site and year. The substrate effect was tested first as a main effect across sampling sites, then again separately within each site for each taxon. Because the response variable was count data with abundant zeros, the best-fit model was a negative binomial model with $\log$ link function. Model fit was tested assuming model deviance was distributed as a chi-square variable with the residual degrees of freedom. In these models, sampling site was considered a fixed factor, because the individual substrate effect at each site is of interest independently of all other sites. Final model included site, year, substrate and site $\times$ substrate interaction for all GLM analyses. GLMs were also used to test for differences in the number of species and the total share of Peracarida between two substrate types. Poisson distribution was the best-fit model (link function: $\log$ ) for number of species and quasibinomial distribution (link function: logit) for proportion of Peracarida in total abundance of macroinvertebrates. All these analyses were performed with the R 3.4.3. (R Development Core Team, 2017) using packages MASS, pscl and mgcv. Due to multiple testing, Bonferroni corrected $p$ values were used for different number of valid tests in each of three groups of GLM analyses (abundance: $n=40$; species number and Peracarida proportion: $n=15$ ).

The spatial pattern of Peracarida assemblages along whole Sava was analyzed using non-parametric multidimensional scaling (NMDS) and PERMANOVA with software package PRIMER Version 6.1.13. and PERMANOVA+ Version 1.0.3 (PRIMER-E Ltd 2009). Average abundance of all Peracarida taxa at all site-year combinations was square-root transformed to control the influence of dominant species and the BrayCurtis index of similarity was used to calculate the similarity matrix. Differences between groups which were clearly different in NMDS plots were tested using PERMANOVA and SIMPER analysis. Two separate data sets (1. - average abundance at 61 sites in all years, 2. - 15 sites where between substrate differences were examined) where analyzed using nested PERMANOVA (site-groups nested in years) to test effects of both factors and differences between two distinguished site-groups identified in NMDS. SIMPER analysis was used to identify taxa that contribute the most to dissimilarity between tested groups. Differences in Peracarida assemblages between natural and artificial substrates at 15 sites, for each of the two distinguished groups of sites separately (native dominated-sites 21 and 23, and alien dominated-other 13 sites), were tested using crossed design in PERMANOVA. Sampling site, substrate and year were considered fixed factors and after testing main effects and site $\times$ substrate interaction, the effect of substrate was tested within each site and year separately using pair-wise tests in PERMANOVA with Bonferroni correction for multiple testing (10 valid tests in second-alien group of sites).

\section{Results}

\subsection{Longitudinal pattern of Peracarida assemblages in the Sava River}

A total of 14 species of peracarid crustaceans ( 5 native and 9 alien) were recorded at 61 sites along the entire course of the Sava River (Fig. 2): 11 amphipods (4 native and 7 alien), 2 isopods (1 native, 1 alien) and an alien species of Mysida (L. benedeni). Multivariate analysis of Peracarida assemblages (Fig. 3), revealed two major groups of sites: sites from the Alpine to the beginning of the Middle Sava (Upper third of Sava course) that contained only native species, and sites dominated by alien species along the Middle and Lower Sava sections. These two sections had clearly different Peracarida assemblages (PERMANOVA, pseudo- $F$ : 22.7, $p=0.0001$ ), 


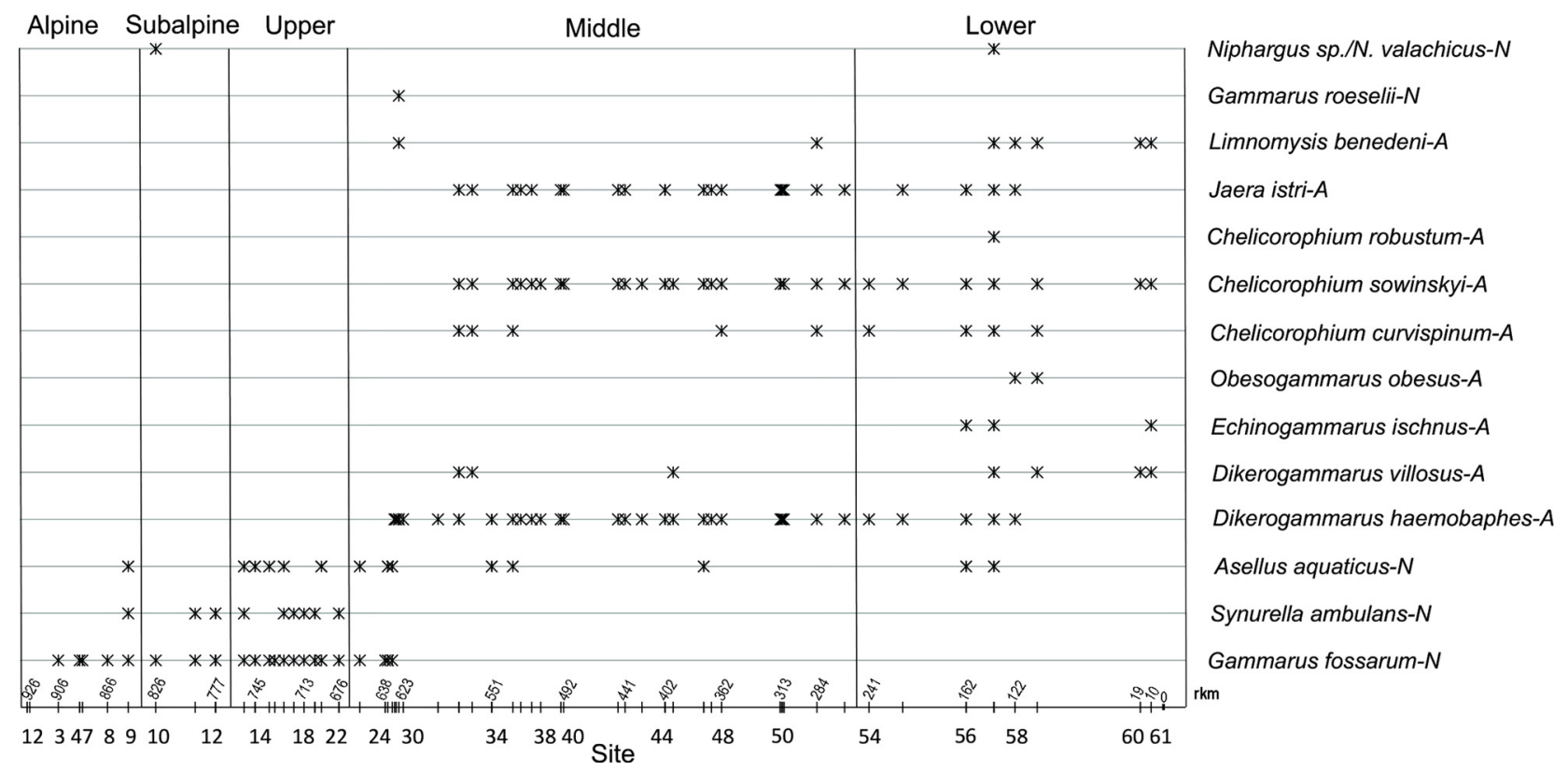

Fig. 2. Distribution of 14 Peracarida species along the entire course of the Sava River with identified river sections (two sites 5 and 6 on the Sava Bohinjka without peracarid crustaceans are not shown; $\mathrm{N}$ - native, A - alien species). Sites are arranged according to the distance from the source of the Sava Dolinka and river kilometers ( $\mathrm{rkm})$ are shown above $x$-axis.

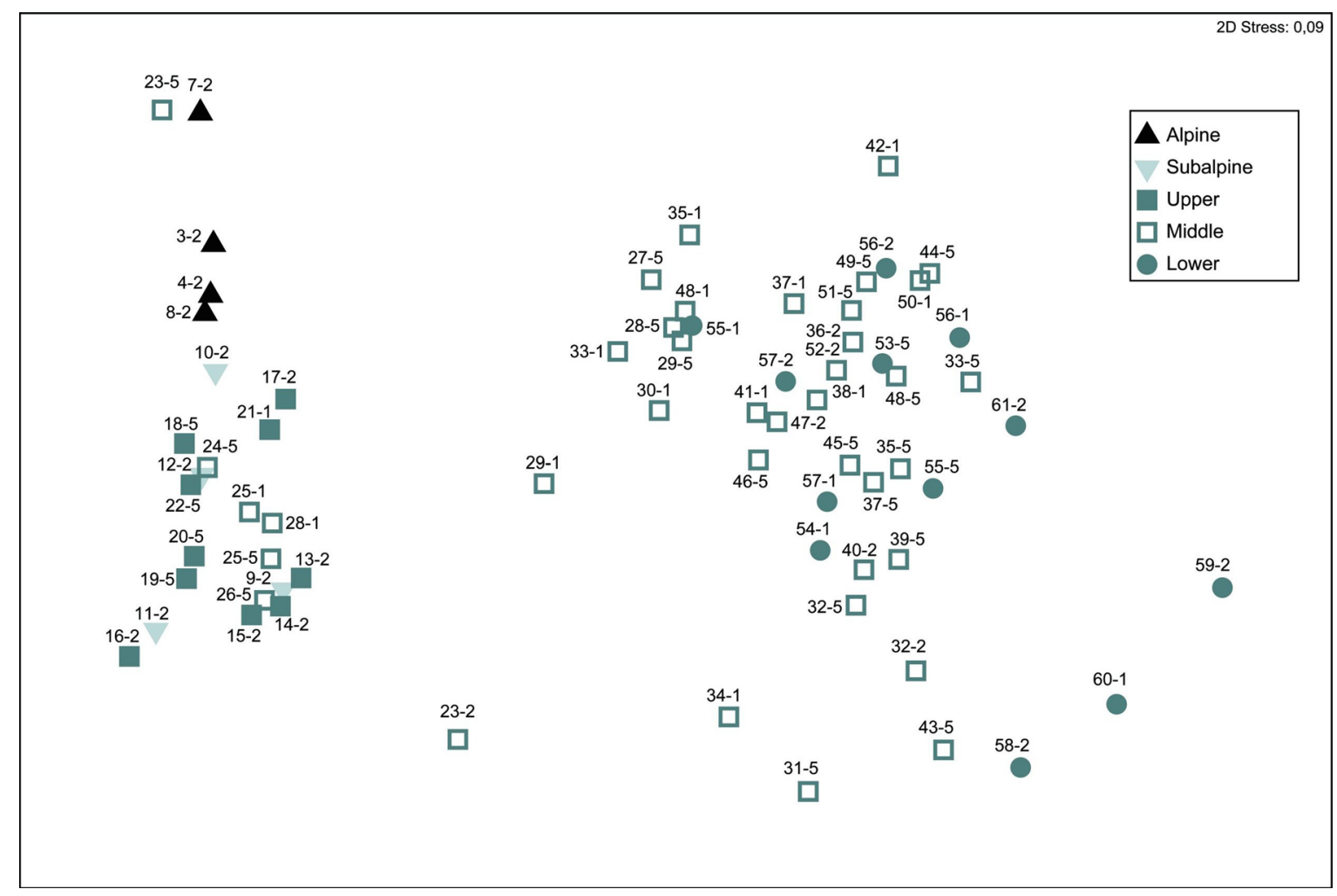

Fig. 3. Non-parametric multidimensional scaling analysis (NMDS) of peracarid assemblages at 57 sites in the Sava (sites $1,2,5,6$ without peracarid species were excluded); (labels: first number - site codes as in Figure 1, second number - the year of sampling, 1-2011, 2-2012, 5-2015).

with non-significant effect of year of sampling (PERMANOVA, pseudo- $F$ : $0.05, p=0.71)$. Average dissimilarity of these two groups of sites was $98.6 \%$ (SIMPER analysis), with native Gammarus fossarum Koch, 1836 specific for the first and D. haemobaphes, Chelicorophium sowinskyi (Martynov, 1924) and $J$. istri for the second group. 


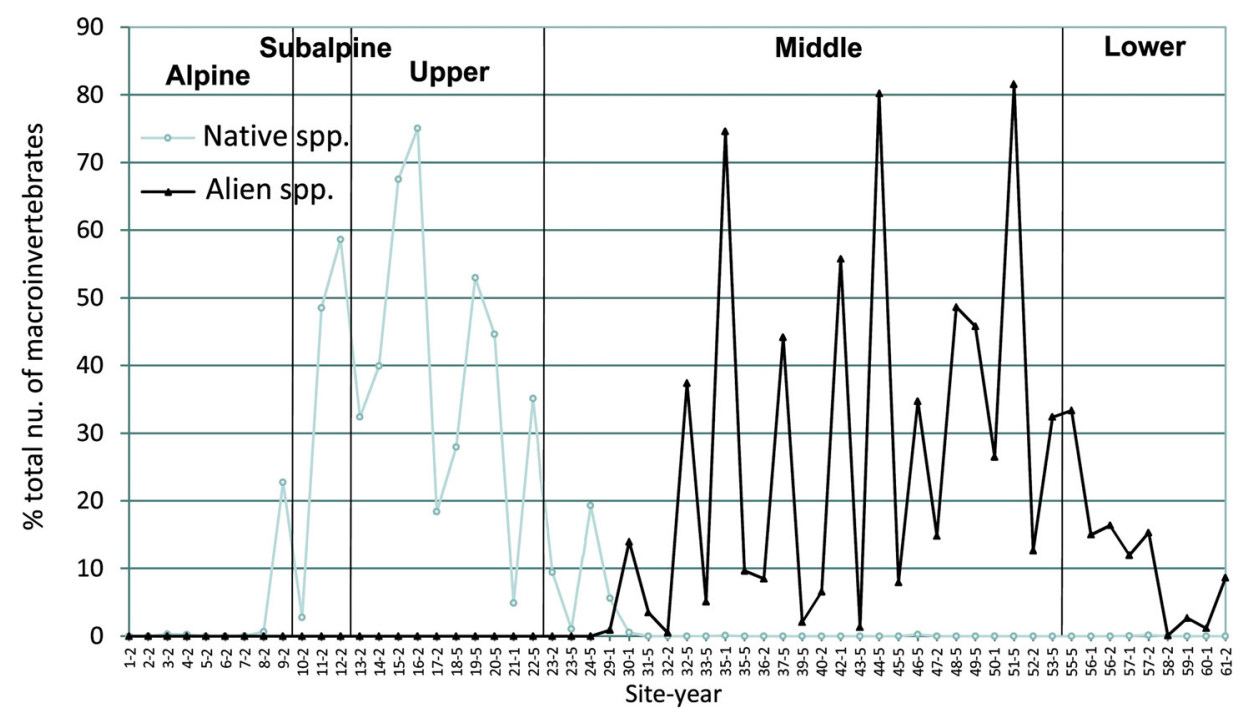

Fig. 4. Relative abundance of native and alien peracarid crustaceans (Amphipoda + Isopoda + Mysida) in macroinvertebrate assemblages along the five sections of the Sava River; ( $x$-axis labels: first number - site codes as in Figure 1, second number - the year of sampling, 1-2011, 2-2012, 5-2015).

The most widespread native species were G. fossarum (at 22 sites) and Asellus aquaticus (L. 1758) (14 sites) (Fig. 2). G. fossarum had a very low abundance in the Alpine Sava, which abruptly increased at the last site of this section (Fig. 4). No peracarid crustaceans were found at the four most upstream sites (sites 1 and 2 in the Sava Dolinka, and sites 5 and 6 in the Sava Bohinjka). Only one specimen of Gammarus roeselii Gervais, 1835 was recorded at site 29 and only in 2011. Of nine alien Peracarida, only three species, D. haemobaphes (identified at 31 sites), C. sowinskyi (27 sites) and J. istri (22 sites) were omnipresent in the Middle and Upper section of Lower Sava, while at sites 58-60 of Lower Sava alien peracarids had very low densities. Some of the recorded peracarid invasive species, Chelicorophium robustum (G.O. Sars, 1895), Echinogammarus ischnus (Stebbing, 1899) and Obesogammarus obesus (Sars G.O., 1894), were recorded for the first time but only in the Lower Sava (Fig. 2). In the 37 sites where Chelicorophium amphipods were found, C. sowinskyi was more widespread (at 34 sites) than C. curvispinum (10 sites), while at most sites (32) C. sowinskyi was the more abundant species.

During this study (2011-2015) an upstream range expansion of the invasive amphipods D. haemobaphes and D. villosus was observed. The upstream range extension of the most upstream invader $D$. haemobaphes was slow $(0.9 \mathrm{~km}$ $\mathrm{yr}^{-1}$ ) (Fig. 1). Although, the native species $G$. fossarum and $A$. aquaticus, were more abundant than $D$. haemobaphes at site 29 in 2011, when $G$. roeselii was also found, only $D$. haemobaphes was found in 2015 at this site. Further, site 27 was inhabited by G. fossarum and A. aquaticus in 2011, whereas in 2015 only $D$. haemobaphes was found there. In contrast to the slow spread of $D$. haemobaphes, D. villosus which was found only in the Lower Sava (from 10 to $139 \mathrm{rkm}$ ) in 2011 and 2012, in 2015 D. villosus suddenly appeared at three sites in the Middle Sava (from 401 to $579 \mathrm{rkm}$ ). Thus, this species has spread $440 \mathrm{~km}$ upstream and it seems that it has already replaced the previous invader, $D$. haemobaphes, at site
33. The upper distribution limit of other widespread invasive crustaceans, C. sowinskyi, C. curvispinum and J. istri, as well as $D$. villosus, was at $579 \mathrm{rkm}$ (site 32 ) and for the first three species did not change from 2012 to 2015.

The total number of Peracarida species increased in a downstream direction from one species ( $G$. fossarum) in the Alpine Sava, four and three in Subalpine and Upper Sava, 9 (3 native and 6 alien) in Middle Sava and 11 (2 native and 9 alien) species in the Lower Sava. The relative proportion of native species in the total abundance of collected macroinvertebrates (Fig. 4), increased from less than $1 \%$ in the Alpine Sava to an average of $40 \%$ in the Upper section. The Alpine section could be distinguished by the low density of $G$. fossarum. This species was predominant in terms of abundance in the Subalpine and Upper Sava, where either S. ambulans or $A$. aquaticus were the subdominant species. The proportion of alien peracarids in total abundance of macroinvertebrates in the Middle and Lower sections exhibited substantial variation (range $0.1-82 \%$ ), with higher average proportion in Middle $(24 \%)$ than Lower section (9\%). The last four sites of Lower Sava had the lowest average proportion of alien Peracarida $(3 \%)$. The high diversity of peracarid assemblages in the Middle and Lower Sava, with different combinations of dominant invasive species (Chelicorophium spp., D. haemobaphes and D. villosus), caused high overlap of sites at these two sections in Figure 3. Only sites with low density of invasive peracarids (three sites in Lower Sava) or sites with only one species found could be clearly distinguished from the main cluster of sites in these two sections.

\subsection{Microdistribution of Peracarida on natural and artificial substrates}

The significant differences in abundance at two substrate types across all sampling sites (where particular taxon or taxon group was present) were established in most cases (GLM, $p<0.001$ ), except for native amphipod $G$. fossarum and alien 
mysid L. benedeni (GLM, $p>0.5$; Tab. 1 in Supplementary material). In all significant cases overall average abundance was 2-96 times higher on artificial substrate. There was also significant effect of site for all taxa/taxon groups, due to large differences in abundance between particular sites, with significant effect of year of sampling for most cases (6 of 9 tested cases) and significant interactions of site and substrate factors (6 of 10). In four cases of significant site and substrate interaction detected, direction of differences (artificial $>$ natural) were the same across sites and only magnitudes differed. For two taxa, D. haemobaphes and Chelicorophium sp., two sites (i.e. one site for each taxa) with significantly different direction (natural $>$ artificial) were detected.

Of eight tests for native species for each site separately, two cases of significantly higher abundance on artificial substrate were established (GLM, $p<0.001$ ) (Fig. 5). For other six nonsignificant cases, in four cases densities of two native species were too low at both substrate types and tests were considered unreliable (densities at both substrate types $<2$ ind. $\mathrm{m}^{-2}$ ).

Of altogether 59 possible tests for six alien taxa and alien taxon group, 23 were considered unreliable due to very low abundance of particular taxon at both substrate types (density $<2$ ind. $\mathrm{m}^{-2}$ ) and were not done (Fig. 5: n.t.-not tested). Therefore, of 36 reliable tests for alien taxa or taxon group in most cases ( 28 or $78 \%$ ) significantly higher (applying Bonferroni correction) abundance was established on artificial substrate (GLM, $p<0.001$ ), with only one case $(3 \%)$ of significantly higher abundance (GLM, $p<0.001)$ on natural substrate (D. haemobaphes at site 50$)$ and seven cases $(19 \%)$ of non-significant differences between two substrate types (GLM, $p>0.05$ ). Of altogether 27 species-site cases which were not tested, in $21(78 \%)$ cases density was higher at artificial substrate.

Significantly higher average number of species on artificial substrate was established for all sites combined together (GLM, $p<0.001$ ). Of altogether 15 tests for between substrate differences in average species number at each site separately, there were seven cases (47\%, with Bonferroni corection) of significantly higher number of species on artificial substrate (GLM, $p<0.005)$. In all other cases difference between substrates in average number of species per sample was not significant (GLM, $p>0.05$ ).

Significantly higher average proportion of Peracarida in total abundance of macroinvertebrates on artificial substrate was established for all sites combined together (GLM, $p<0.001)$. There were altogether seven cases $(47 \%$, with Bonferroni corection) of significantly higher proportion of Peracarida in total abundance of macroinvertebrates on artificial substrate (GLM, $p<0.05$ ), two significant cases of natural $>$ artificial (GLM, $p<0.001)$, and six cases of nonsignificant differences between substrates.

Preliminary check of data set (218 non-zero samples) used for testing differences in Peracarida assemblages between two substrate types at 15 sites revealed two groups of sites: (1) sites 21 and 23 where only native species occurred and (2) other 13 sites dominated by alien species. These two groups were significantly different (PERMANOVA, pseudo- $F=33.4$, $p=0.0001$ ) and subsequently analyzed separately. There was significant site effect (pseudo- $F=45.7, \quad p=0.0001$, crossed PERMANOVA, year factor not included) in first native-group, while effect of substrate was not significant (pseudo- $F=0.96, p=0.41$ ). For second group dominated by alien species, there were significant effects of all factors, site (crossed PERMANOVA, pseudo- $F=11.1, p=0.0001$ ), substrate (pseudo- $F=14.2, p=0.0001$ ) and year (pseudo- $F=6.1$, $p=0.0001)$, as well as significant site $\times$ substrate interaction (pseudo- $F=4.2, p=0.0001$ ). Pair-wise tests for between substrate differences of Peracarida assemblages were reliable (if nu. of permutations $>10$ ) for 9 of 13 sites dominated by alien species (at sites 32, 52, 58, 60 tests were unreliable with very small number of unique permutation due to only one or two samples with peracarids on natural substrate). Significant difference between substrates, due to higher densities of aliens on artificial substrate, were established at four sites (PERMANOVA pair-wise tests, pseudo- $F=2.6-3.2, \quad p$ $<0.001)$, while at five sites these differences were nonsignificant (pseudo- $F=1.16-1.50, p>0.05$ ). Only at site 50 significant difference between peracarid assemblages on two substrate types (pseudo- $F=4.0, p=0.0002$ ) were due to higher densities of D. haemobaphes and Chelicorophium sp. on natural substrate (Tab. S1 in Supplementary material).

\section{Discussion}

\subsection{Distribution}

Peracarid fauna in the Sava River, with 5 native and 9 alien species, had following distribution pattern during the course of this study (2011-2015): only native species inhabited Upper third of Sava and aliens dominated the rest of the course. Further, interesting distribution pattern of alien peracarid crustaceans was observed: the highest densities and abundance contamination of macroinvertebrate assemblages by alien peracarids was not in the Lower Sava section as expected, but in the Middle Sava section. The Lower Sava on the other hand had the highest number of alien peracarid species (all 9 species), most of which were found in low densities. Since many physicochemical parameters in the Middle and Lower Sava sections did not differ significantly and as pollution at some sites in the Middle Sava section was even higher than in the Lower Sava (unpublished results), physicochemical parameters were probably not responsible for the observed differences. Higher propagule pressure due to more intensive ship traffic and the proximity of the Danube as a source of new alien species appears to be the main reason for the higher number of alien species in the Lower Sava section. The higher abundance contamination in the Middle Sava, on the other hand, could be attributed to the higher share of coarse fractions in the sediment (especially at the confluences of larger tributaries), i.e. more muddy bottoms in the Lower Sava.

In comparison with the Danube, two of the seven "ubiquitous" alien species recorded in the Danube $(D$. haemobaphes and $J$. istri $=J$. sarsi in Borza et al., 2015), were also recorded in the most of the sites examined in the Sava River. Further, D. villosus, as the most widespread species in the Danube, exhibited a disjunctive distribution in the Sava: it was first recorded only in the Lower Sava (in 2011 and 2012) and in 2015 it appeared at three sites of the Middle Sava. Dispersal of D. villosus from the Lower Sava or Danube River to the Middle Sava section probably occurred by transport on ships or on small fishing boats. Judging from its invasion rates in other large European rivers (e.g. Bollache 

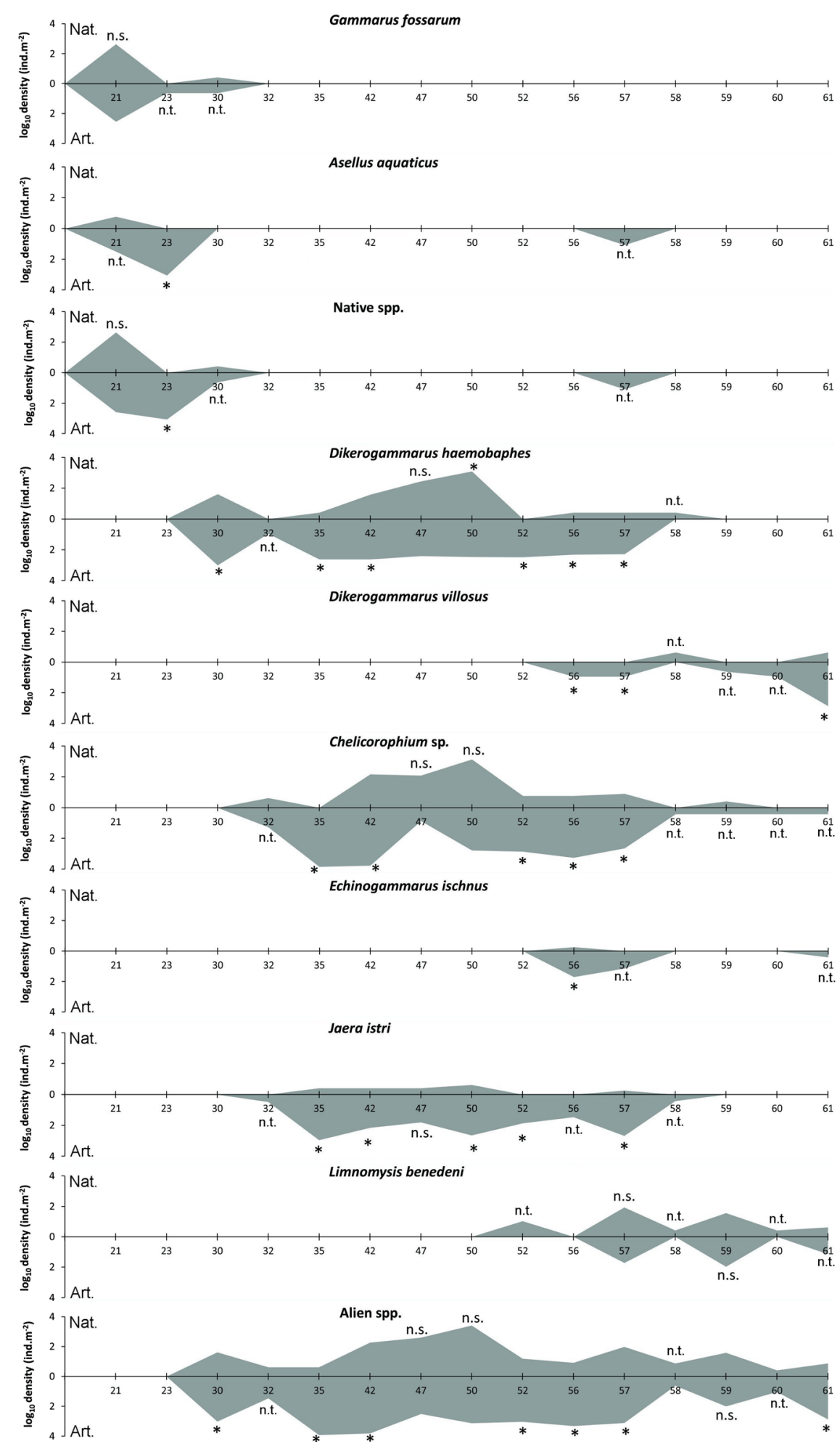

Fig. 5. Density ( $\log _{10}$-transformed) on natural (Nat.- above $\mathrm{x}$-axis) and artificial substrate (Art.-below $x$-axis) of seven species, Chelicorophium sp., and native and alien species grouped together at 15 sites where the density was established by replicate sampling $(n=10)$ on two types of microhabitats. *Significant differences (GLM for count data with Bonferroni correction; n.s.-not significant, n.t.-not tested if density $<2$ ind. $\mathrm{m}^{-2}$ ).

et al., 2004; Van Riel et al., 2006), as well in the Drava River in Croatia (Žganec, unpublished), D. villosus spread through the Middle Sava can be expected to be fast. Also, it could be expected, similarly to other documented cases (review in Rewicz et al., 2014) and situation in Drava (unpublished results), that it will eliminate the previous invader, $D$. 
haemobaphes. Further, while some studies of the interaction of $D$. villosus and D. haemobaphes showed that D. villosus is stronger competitor (Kobak et al., 2016), others did not found D. villosus to be the more resilient competitor/predator (Kinzler et al., 2009). Also, since many field studies have reported on the co-occurrence of these two species (e.g. Labat et al., 2011; Borza et al., 2015), and since we found such cooccurrence at site 57 , it seems that in some situations long-term coexistence of these two species is possible. Ongoing invasion of the Middle Sava by D. villosus provides excellent opportunity for the future studies that should examine interactions of these two invaders in the Middle Sava. Distributions and densities of other two most important invasive amphipods, C. sowinskyi and C. curvispinum, were different in Sava from those in Danube. In Sava C. sowinskyi was more widespread and more abundant species than $C$. curvispinum. These results suggest that either $C$. sowinskyi was the first colonizer of the Sava, whereas C. curvispinum arrived later, as suggested by Borza (2011) for Hungarian freshwater or that $C$. curvispinum is less well adapted to conditions in Sava and may be the weaker competitor. The finding of invasive alien amphipod $C$. robustum at one site in the Lower Sava should also be pointed out. This species probably recently started to expand its range from the Danube into the Lower Sava, since in Danube it is in the process of spreading downstream and closing its distribution gap in the Middle Danube (Borza et al., 2015).

The first records of alien peracarids in the Sava, two alien amphipod taxa (Corophium sp. and Pontogammarus sp.) and alien isopod Jaera sp., date back to the 1970s when only a previous longitudinal study of macroinvertebrates along the entire watercourse of the Sava (at 41 sites) was conducted (Matoničkin et al., 1975). Despite misidentifications of some species in this first study (D. haemobaphes probably misidentified as Pontogammarus), using the upstream distribution fronts of $D$. haemobaphes, Chelicorophium spp. and $J$. istri from Matoničkin et al. (1975), as well as from study in 2004 (Žganec et al., 2009) and personal unpublished records from 2009, upstream distribution range expansion rates of three invasive species could be estimated: D. haemobaphes (avg: 18.4, range: 0.9-54.5 $\mathrm{km}$ year $^{-1}$ ), Chelicorophium $\mathrm{sp}$. (avg: 15.8, range: 1.6-30.0 $\mathrm{km}^{-1} \mathrm{yr}^{-1}$ ) and J. istri (avg: 11.7, range: $6.6-16.7 \mathrm{~km}$ year $^{-1}$ ). Similar estimates of upstream range expansion rates for D. villosus $\left(30-40 \mathrm{~km} \mathrm{year}^{-1}\right)$ and $C$. curvispinum $\left(8-17 \mathrm{~km}\right.$ year $\left.^{-1}\right)$ were reported for the Meuse River in France (Josens et al., 2005), while much higher mean dispersal rates but similar minimum dispersal rates for the same two species and $J$. istri were observed in the Rhine (Leuven et al., 2009). Our estimates are probably the lowest documented values, especially in the case of $D$. haemobaphes, which showed a slow upstream spread of $0.9 \mathrm{~km}_{\text {year }}{ }^{-1}$ during study period (2011-2015). This could be because the reach of the Sava where this was observed is not used for navigation and probably only small fishing boats could facilitate the spread. Another important factor is the distribution of bank riprap reinforcement structures that are scattered between locations with stronger bank erosion and long stretches of natural banks in this Upper part of the Middle Sava. Therefore, it can be assumed that more natural hydromorphology at this part of Sava and absence of shipping traffic disables faster upstream spread of invasive amphipod D. haemobaphes.
Furthermore, the upstream spread of two Chelicorophium species and $J$. istri in Sava appears to have halted at site 32 (rkm 579), which is very close to Sisak (rkm 594) up to where navigation is possible. This finding indicates that shipping probably served as the main vector of spread of these three species in the Sava. Also, since the first sites upstream of site 32 possess different physicochemical conditions indicative of increased pollution (unpublished data), it is possible that certain factors in this part of the Sava, beside lack of dispersal vectors, have inhibited further upstream spread of three invasive peracarids, C. sowinskyi, C. curvispinum and J. istri. Finally, as range expansion of invaders might occur through non-continuous processes (jump dispersal patterns) which can also be human-mediated (Mineur et al., 2010), and as multiple dispersal pathways might occur within the same ecosystem (Suarez et al., 2001), long-term data-sets are required to capture all patterns.

The upstream spread of $D$. haemobaphes appears to have caused disappearance of the native species, $G$. fossarum, $G$. roeselii and $A$. aquaticus at the beginning of Middle Sava. The predatory behavior of this species was shown to be similar to that of the better-known "killer shrimp", D. villosus (BacelaSpychalska and Van der Velde, 2013). Accordingly, it can be assumed that $D$. haemobaphes will slowly spread further upstream in Upper Sava where it is expected to eliminate native peracarids ( $G$. fossarum, S. ambulans and A. aquaticus). Similar cases of upstream spread of invasive Dikerogammarus amphipods that has led to the disappearance of native species were observed in many other large rivers (Bollache et al., 2004; Josens et al., 2005; Grabowski et al., 2007; Borza et al., 2015). However, Hellmann et al. (2017) showed that impact of D. villosus on benthic assemblage was weak and differed between two studied rivers. Hence, with this study as baseline, future studies of the spread of invasive peracarid crustaceans in Sava should concentrate on their impact on macroinvertebrate assemblages.

\subsection{Artificial substrates as "exotic paradise" microhabitats that facilitate invasion}

In this study we observed strong preferences of artificial coarser stony substrate (macro-, meso- and megalithal on riprap embankments and groynes) over finer natural substrate (gravel, sand and mud) by alien peracarids. At most sites, alien species had higher densities on artificial substrate and often these differences were significant (Fig. 5). Also, the Peracarida assemblages on natural and artificial substrates significantly differed at almost half of sites due to the much higher abundance of Dikerogammarus spp., Chelicorophium spp. and $J$. istri, on artificial substrates. In the literature these tree taxa were described as "lithophilous dwellers" (Jazdzewski, 1980; Bij de Vaate et al., 2002). Further, numerous previous field studies established high densities of alien amphipods and isopods on artificial stony structures: for D. villosus (Devin et al., 2003; Van Riel et al., 2006; MacNeil et al., 2008; Boets et al., 2010; MacNeil and Platvoet, 2013), D. haemobaphes (Environment Agency, 2012), E. ischnus (Van Overdijk et al., 2003), C. curvispinum (Van der Velde et al., 2000) and isopod J. istri (Kelleher et al., 2000). Here we also showed that samples from natural substrates often did not contain alien amphipods and isopods, although high densities of aliens were found on artificial substrates. Also, we noted that the average 
numbers of alien peracarid species per sample at many sites were significantly higher on artificial substrate, and the same was observed for peracarid share in the entire benthos. Obviously, alien amphipods and isopod $J$. istri show strong preference for artificial substrate. This could be explained by higher artificial substrate stability during high discharge events and the fact that these microhabitats provide refugia not only from strong current but also from fish predators. Furthermore, large stones of artificial substrate probably act as traps for coarse particular organic matter (CPOM), what makes them even more attractive for alien gammarids, while for Chelicorophium species they provide perfect stable surfaces for attachment of mud tubes in which they live. Therefore, similarly to conclusions of MacNeil and Platvoet (2013) for $D$. villosus, this study showed that in order to detect amphipod and isopod invaders, sampling protocols should be adapted to always include any large stone or concrete structures on artificial substrate. However, one case with higher density on natural substrates was observed for $D$. haemobaphes at site 50). This site is hundred meters from the confluence of the Bosna River, where the natural substrate contained a higher proportion of a coarser substrate. It was shown that tributaries exert a significant effect on the substrate and on the physicochemical parameters in large rivers, thereby inducing variability in longitudinal changes of macroinvertebrate assemblages (Rice et al., 2001). Hence, future studies could examine whether the confluences of larger tributaries, because of higher proportion of coarser substrate components, represent sites with higher densities of invasive pericarids. Therefore, confluences of larger tributaries could represent natural stepping stones that facilitate the invasion of peracarid crustaceans. When different artificial structures, especially riprap stony structures and groynes, are introduced to the main watercourse, reaches on the river with a few favorable places can easily be transformed into a chain of microhabitats where lithophilous alien amphipods and isopods find their "paradise microhabitats". Since most large European rivers have been transformed by channel modification structures in a similar way to the Sava, and probably much more intensively, this type of anthropomorphic pressure could be one of the main reasons for the very rapid expansion of the range of most aquatic invasive peracarids across Europe.

\section{Conclusions}

This study is the most detailed investigation of peracarid assemblages along the entire course of the Sava River in the last 40 years (since Matoničkin et al., 1975), and offers a detailed insight into differences in composition and density of peracarid crustaceans assemblages on natural and artificial substrates along the Sava River. It represents a baseline for future assessments of the impact of the spread of invasive peracarids and other pressures on macroinvertebrate assemblages. The Sava is the main corridor through which invasive species could spread into Dinaric karst rivers that support endemic macroinvertebrate fauna and other biota. Therefore, a deeper understanding of dispersal patterns and pathways as well as the changes in the macroinvertebrate fauna that inhabit the Sava is of pivotal importance for the conservation of freshwater biodiversity of Western Balkan rivers.

\section{Supplementary Material}

Table S1. Results of all tests for all taxa and taxon groups, with all 15 sites combined and for each site separately: (1) generalized linear models for abundance (density data showed), (2) species number and (3) proportion of Peracarida in total macroinvertebrate abundance, (4) crossed PERMANOVA for each of two distinguished groups of sites separately (native and alien site groups) with pair-wise tests for between substrate differences at each site separately. Bonferroni-corrected $p$-values were separately calculated for abundance data $(p=0.05 / 40=0.00125)$, species number and proportion of Peracarida $(p=0.05 / 15=0.0033)$ and PERMANOVA pair-wise tests $(p=0.05 / 10=0.005)$.

The Supplementary Material is available at https://www. limnology-journal.org/10.1051/limn/2018008/olm.

Acknowledgements. This work is the result of two projects supported by Ministry of Science, Education and Sports of the Republic of Croatia, Ministry of Education, Science and Technological Development of the Republic of Serbia and Ministry of Higher Education, Science and Technology of the Republic of Slovenia, project periods 2011-2012 and 20122013. We also wish to thank for financial support by GLOBAQUA project that has been supported by European Communities 7th Framework Programme Funding under Grant agreement no. 603629-ENV-2013-6.2.1 (Globaqua). Sampling along Croatian section of Sava in 2015 was supported by Croatian Water and Management Agency. We thank Prof. Stewart Schultz, University of Zadar, for help with GLM analyses in R and for linguistic improvements. Also, three unknown referees are thanked for their critical remarks that greatly improved earlier versions of the manuscript.

\section{References}

Andersen CB, Žganec K. 2016. Impact of Zagreb wastewater treatment plant on the Sava River water quality. In: Annual Meeting of the American Association of Geographers.

Arbačiauskas K, Semenchenko V, Grabowski M, Leuven RSEW, Paunović M, Son MO, Csányi B, Gumuliauskaitė S, Konopacka A, Nehring S, Van der Velde G, Vezhnovetz V, Panov VE. 2008. Assessment of biocontamination of benthic macroinvertebrate communities in European inland waterways. Aquat Invasions 3: 211-230.

Argano R. 1979. Guide per il riconoscimento delle specie animali delle acque interne Italiane. 5. Isopodi (Crustacea, Isopoda). Consiglio nazionale delle ricerche. Verona: Impresso della stamperia Veldonega, $63 \mathrm{p}$.

AQEM Consortium. 2002. Manual for the application of the AQEM system. A comprehensive method to assess European streams using benthic macroinvertebrates, developed for the purpose of the Water Framework Directive. Version 1, 202 p.

Bacela-Spychalska K, Van der Velde G. 2013. There is more than one "killer shrimp": trophic positions and predatory abilities of invasive amphipods of Ponto-Caspian origin. Freshw Biol 58: 730-741.

Bernauer D, Jansen W. 2006. Recent invasions of alien macroinvertebrates and loss of native species in the upper Rhine River, Germany. Aquat Invasions 11: 55-71.

Bij de Vaate A, Jazdzewski K, Ketelaars HA, Gollasch S, Van der Velde G. 2002. Geographical patterns in range extension of 
Ponto-Caspian macroinvertebrate species in Europe. Can J Fish Aquat Sci 59: 1159-1174.

Boets P, Lock K, Messiaen M, Goethals PLM. 2010. Combining datadriven methods and lab studies to analyse the ecology of Dikerogammarus villosus. Ecol Inform 5: 133-139.

Bollache L, Devin S, Wattier R, Chovet M, Beisel J-N, Moreteau JC, Rigaud T. 2004. Rapid range extension of the Ponto-Caspian amphipod Dikerogammarus villosus in France: potential consequences. Arch für Hydrobiol 160: 57-66.

Borza P. 2011. Revision of invasion history, distributional patterns, and new records of Corophiidae (Crustacea: Amphipoda) in Hungary. Acta Zool Acad Sci Hung. 57: 75-84.

Borza P, Csányi B, Huber T, Leitner P, Paunović M, Remund N, Szekeres J, Graf W. 2015. Longitudinal distributional patterns of Peracarida (Crustacea, Malacostraca) in the River Danube. Fundam Appl Limnol 187: 113-26.

Cărăusu S, Dobreanu E, Manolache C. 1955. Amphipoda forme salmastre si de apă dulce. Fauna Republ pop Rom Crustac 4: 1407.

Den Hartog C, Van den Brink FWB, Van der Velde G. 1992. Why was the invasion of the river Rhine by Corophium curvispinum and Corbicula species so successful? J Nat Hist 26: 1121-1129.

Devin S, Beisel JN. 2006. Biological and ecological characteristics of invasive species: a gammarid study. Biol Invasions 9: 13-24.

Devin S, Piscart C, Beisel JN, Moreteau JC. 2003. Ecological traits of the amphipod invader Dikerogammarus villosus on a mesohabitat scale. Arch Fur Hydrobiol 158: 43-56.

Dick JTA, Platvoet D. 2000. Invading predatory crustacean Dikerogammarus villosus eliminates both native and exotic species. Proc. R. Soc. Lond. Ser. B 267: 977-983.

Dobson M. 2012. Identifying invasive freshwater shrimps and isopods. Ambleside: Freshwater Biological Association, 29 p.

Eggers TO, Martens A. 2001. Bestimmungsschlüssel der SüßwasserAmphipoda (Crustacea) Deutschlands. Laurterbornia 42: 1-68.

Environment Agency. 2012. Invasive shrimp (D. haemobaphes) interim briefing note, Environment Agency UK, www.nonnatives pecies.org.

European Environment Agency. 2012. European waters - assessment of status and pressures, Copenhagen: European Environment Agency, $96 \mathrm{p}$.

Gergs R, Rothhaupt K-O. 2015. Invasive species as driving factors for the structure of benthic communities in Lake Constance, Germany. Hydrobiologia 746: 245-254.

Grabowski M, Bacela K, Konopacka A. 2007. How to be an invasive gammarid (Amphipoda: Gammaroidea) - comparison of life history traits. Hydrobiologia 590: 75-84.

Grabowski M, Bacela K, Konopacka A, Jazdzewski K. 2009. Salinity-related distribution of alien amphipods in rivers provides refugia for native species. Biol Invasions 11: 2107-2117.

Hellmann C, Schöll F, Worischka S, Becker J, Winkelmann C. 2017. River-specific effects of the invasive amphipod Dikerogammarus villosus (Crustacea: Amphipoda) on benthic communities. Biol Invasions 19: 381-398.

Holdich DM, Pöckl M. 2007. Invasive crustaceans in European inland waters. In: Gherardi F, ed. Biological invaders in inland waters: profiles, distribution, and threats. Dordrecht: Springer, pp. 29-75.

ICPDR. 2005. The Danube River Basin District. River basin characteristics, impact of human activities and economic analysis. Part A - Basin-wide overview. International Commission for the Protection of the Danube River (ICPDR), Vienna, Austria.

Jazdzewski K. 1980. Range extensions of some gammaridean species in European inland waters caused by human activity. Crustaceana 6: 84-107.
Jazdzewski K, Konopacka A, Grabowski M. 2002. Four PontoCaspian and one American gammarid species (Crustacea, Amphipoda) recently invading Polish waters. Contrib Zool 71: $115-122$.

Josens G, De Vaate AB, Usseglio-Polatera P, Cammaerts R, Chérot F, Grisez F, Verboonen P, Vanden Bossche JP. 2005. Native and exotic Amphipoda and other Peracarida in the River Meuse: new assemblages emerge from a fast changing fauna. Hydrobiologia 542: 203-220.

Karaman GS, Pinkster S. 1977a. Freshwater Gammarus species from Europe, North Africa and adjacent regions of Asia (Crustacea Amphipoda) Part I. Gammarus pulex - group and related species. Bijdr Dierkd 47: 1-97.

Karaman GS, Pinkster S. 1977b. Freshwater Gammarus species from Europe, North Africa and adjacent regions of Asia (Crustacea Amphipoda) Part II. Gammarus roeseli - group and related species. Bijdr Dierkd 47: 165-96.

Karatayev AY, Burlakova LE, Padilla DK, Mastitsky SE, Olenin S. 2009. Invaders are not a random selection of species. Biol Invasions 11: 2009-2019.

Kelleher B, Bij de Vaate A, Swarte M, Klink AG, Van der Velde G. 2000. Identification, invasion and population development of the Ponto-Caspian isopod Jaera istri Veuille (Janiridae) in the Lower Rhine, the Netherlands. Beaufortia Bull Zool Mus Univ Amst 50: 89-94.

Kinzler W, Kley A, Mayer G, Waloszek D, Maier G. 2009. Mutual predation between and cannibalism within several freshwater gammarids: Dikerogammarus villosus versus one native and three invasives. Aquat Ecol 43: 457-464.

Kobak J, Rachalewski M, Bacela-Spychalska K. 2016. Conquerors or exiles? Impact of interference competition among invasive PontoCaspian gammarideans on their dispersal rates. Biol Invasions 18: 1953-1965.

Komatina D, Grošelj S. 2015. Transboundary water cooperation for sustainable development of the Sava River Basin. In: Milačič R, Ščančar J, Paunović M, eds. The Sava River. The handbook. Berlin/ Heidelberg: Springer, pp. 1-28.

Labat F, Piscart C, Fontan B. 2011. First records, pathways and distributions of four new Ponto-Caspian amphipods in France. Limnologica 41: 290-295.

Leuven RSEW, Van der Velde G, Baijens I, Snijders J, van der Zwart C, Lenders HJR, Bij de Vaate A. 2009. The river Rhine: a global highway for dispersal of aquatic invasive species. Biol Invasions 11: 1989-2008.

Lodge DM. 1993. Biological invasions: lessons for ecology. Trends Ecol Evol 8: 133-137.

Lucić A, Paunović M, Tomović J, Kovačević S, Zorić K, Simić V, Atanacković A, Marković V, Kračun-Kolarević M, Hudina S, Lajtner J, Gottstein S, Milošević Đ, Anđus S, Žganec K, Jaklič M, Simčič T,Vilenica M. 2015. Aquatic macroinvertebrates of the Sava River. In: Milačič R, Ščančar J, Paunović M, eds. The Sava River. The handbook. Berlin/Heidelberg: Springer, pp. 335-359.

Macneil C, Platvoet D. 2013. Could artificial structures such as fish passes facilitate the establishment and spread of the "killer shrimp" Dikerogammarus villosus (Crustacea: Amphipoda) in river systems? Aquat Conserv 23: 667-77.

MacNeil C, Platvoet D, Dick JT. 2008. Potential roles for differential body size and microhabitat complexity in mediating biotic interactions within invasive freshwater amphipod assemblages. Fundam Appl Limnol 172: 175-182.

Maguire I, Jelić M, Klobučar G. 2011. Update on the distribution of freshwater crayfish in Croatia. Knowl Manag Aquat Ecosyst 401: $1-10$. 
Marković V, Tomović J, Atanacković A, Kračun M, Ilić M, Nikolić V, Paunović M. 2015. Macroinvertebrate communities along the Velika Morava River. Turkish J Zool 39: 210-224.

Matoničkin I, Pavletić Z, Habdija I, Stilinović B. 1975. A contribution to the valorisation of waters of the ecosystem of river Sava. Sveučilišna naklada Liber, Zagreb, 96 p.

Meštrov M, Dešković I, Tavčar V. 1978. Pollution of the river Sava according to several years of ecological research. Ekologija 13:61-79.

Meštrov M, Habdija I, Stilinović B, Maloseja Ž, Tavčar V, Kerovec M, Primc B, Futač N. 1989. Biološko-ekološka valorizacija kvalitete vode rijeke Save. In: Meštrov M, ed. Rijeka Sava-zaštita i korištenje voda. Vol. 14, Zagreb: JAZU, 290-308.

Mineur F, Davies AJ, Maggs CA, Verlaque M, Johnson MP. 2010. Fronts, jumps and secondary introductions suggested as different invasion patterns in marine species, with an increase in spread rates over time. Proc R Soc Lond B 277: 2693-2701.

Nunes AL, Tricarico E, Panov VE, Cardoso AC, Katsanevakis S. 2015. Pathways and gateways of freshwater invasions in Europe. Aquat Invasions 10: 359-370.

Ogrinc N, Kanduč T, Kocman D. 2015. Integrated approach to the evaluation of chemical dynamics and anthropogenic pollution sources in the Sava River Basin. In: Milačič R, Ščančar J, Paunović M, eds. The Sava River. The hanbook. Berlin/Heidelberg: Springer, pp. 75-94.

Paunović M, Miljanović B, Simić V, Cakić P, Djikanović V, JakovčevTodorović D, Stojanović B, Veljković A. 2005. Distribution of nonindigenous tubificid worm Branchiura sowerbyi (Beddard, 1892) in Serbia. Biotechnol Biotechnol Equip 19: 91-97.

Paunović M, Tomović J, Kovačević S, Zorić K, Žganec K, Simić V, Atanacković A, Marković V, Kračun M, Hudina S, Lajtner J, Gottstein S, Lucić A. 2012. Macroinvertebrates of the natural substrate of the Sava River - preliminary results. Water Res Manag 2: 33-39.

Petts GE, Möller H, Roux AL. 1993. Historical change in large alluvial rivers: Western Europe, Chichester: Wiley, 355 p.

Pinkster S. 1993. A revision of the genus Echinogammarus Stebbing, 1899 with some notes on related genera (Crustacea, Amphipoda). Mem del Mus Civ Stor Nat 10: 1-185.

R Development Core Team. 2017. A language and environment for statistical computing, Vienna, Austria: R Foundation for Statistical Computing, http://www.R-project.org.

Rewicz T, Grabowski M, MacNeil C, Bącela-Spychalska K. 2014. The profile of a "perfect" invader - the case of killer shrimp, Dikerogammarus villosus. Aquat Invasions 9: 267-288.

Rice SP, Greenwood MT, Joyce CB. 2001. Tributaries, sediment sources, and the longitudinal organisation of macroinvertebrate fauna along river systems. Can J Fish Aquat Sci 58: 824-840.

Schneider-Jacoby M. 2005. The Sava and Drava floodplains. Threatened ecosystems of international importance. Arch für Hydrobiol Supp. 158: 249-288.

Schwarz U. 2016. Sava White Book. The River Sava: threats and restoration Potential. Radolfzell/Wien: EuroNatur/Riverwatch, $144 \mathrm{p}$.

Sommerwerk N, Hein T, Schneider-Jacoby M, Baumgartner C, Ostojić A, Siber R, Bloesch J, Paunović M, Tockner K. 2009. The Danube River Basin. In: Tockner K, Uehlinger U, Robinson CT, eds. Rivers of Europe. London: Academic Press, pp. 59-112.

Statzner B, Peltret O, Tomanova S. 2003. Crayfish as geomorphic agents and ecosystem engineers: effect of a biomass gradient on baseflow and flood-induced transport of gravel and sand in experimental streams. Freshw Biol 48: 147-163.
Statzner B, Bonada N, Dolédec S. 2008. Biological attributes discriminating invasive from native European stream macroinvertebrates. Biol Invasions 10: 517-530.

Strayer DL, Cole JJ, Findlay SEG, Fischer DT, Gephart JA, Malcom HM, Pace ML, Rosi-Marshall EJ. 2014. Decadal-scale change in a large-river ecosystem. Bioscience 64: 496-510.

Suarez AV, Holway DA, Case TJ. 2001. Patterns of spread in biological invasions dominated by long-distance jump dispersal: Insights from Argentine ants. PNAS 98: 1095-1100.

Tierno de Figueroa JM, López-Rodríguez MJ, Fenoglio S, SánchezCastillo P, Fochetti R. 2013. Freshwater biodiversity in the rivers of the Mediterranean Basin. Hydrobiologia 719: 137-186.

Tockner K, Uehlinger U, Robinson CT. (eds.) 2009. Rivers of Europe. London: Academic Press, 728 p.

Urbanič G. 2008. Redelineation of European inland water ecoregions in Slovenia. Rev Hydrobiol 1: 17-25.

Van den Brink FWB, Van der Velde G, Bij de Vaate A. 1993. Ecological aspects, explosive range extension and impact of a mass invader, Corophium curvispinum Sars, 1895 (Crustacea: Amphipoda), in the Lower Rhine (The Netherlands). Oecologia 93: 224-232.

Van der Velde G, Rajagopal S, Kelleher B, Muskó IB, Bij de Vaate A. 2000. Ecological impact of crustacean invaders: general considerations and examples from the River Rhine. In: The biodiversity crisis and Crustacea: Proc 4th Int Crustacean Congress. Vol. 2, Brill, Leiden, Amsterdam, pp. 3-33.

Van Overdijk CDA, Grigorovich IA, Mabee T, Ray WJ, Ciborowski JJH, Macisaac HJ. 2003. Microhabitat selection by the invasive amphipod Echinogammarus ischnus and native Gammarus fasciatus in laboratory experiments and in Lake Erie. Freshw Biol 48: $567-578$.

Van Riel MC, Van der Velde G, Rajagopal S, Marguillier S, Dehairs F, Bij de Vaate A. 2006. Trophic relationships in the Rhine food web during invasion and after establishment of the Ponto-Caspian invader Dikerogammarus villosus. Hydrobiologia 565: 39-58.

Veuille M. 1979. Lévolution du genre Jaera Leach (Isopodes; Asellotes) et ses rapports avec 1histoire de la Méditerranée. Sci Ser 49: 195-217.

Whitton BA. (ed.) 1984. Ecology of European Rivers, London: Blackwell Scientific Publications, 584 p.

Wittmann KJ, Ariani AP, Daneliya M. 2016. The Mysidae (Crustacea: Peracarida: Mysida) in fresh and oligohaline waters of the Mediterranean. Taxonomy, biogeography, and bioinvasion. Zootaxa 4142: 1-70.

Zorić K, Jakovčev-Todorović D, Dikanović V, Vasiljević B, Tomović J, Atanacković A, Simić V, Paunović M. 2011. Distribution of the Ponto-Caspian polychaeta Hypania invalida (Grube, 1860) in inland waters of Serbia. Aquat Invasions 6: 33-38.

Žganec K, Gottstein S, Hudina S. 2009. Ponto-Caspian amphipods in Croatian large rivers. Aquat Invasions 4: 327-335.

Žganec K, Ćuk R, Dekić S, Miliša M. 2016. Biocontamination of benthic macroinvertebrate communities of four major large rivers in Croatia. In: Móra A, Csabai Z, eds. Book of abstracts and programme. 2nd Central European Symposium for Aquatic Macroinvertebrate Research (CESAMIR). Mohács, Pécs: Carpathes Nature Foundation, p. 123.

Žganec K, Lunko P, Stroj A, Mamos T, Grabowski M. 2016. Distribution, ecology and conservation status of two endemic amphipods, Echinogammarus acarinatus and Fontogammarus dalmatinus, from the Dinaric karst rivers, Balkan Peninsula. Ann Limnol 52: 13-26.

Cite this article as: Žganec K, Ćuk R, Tomović J, Lajtner J, Gottstein S, Kovačević S, Hudina S, Lucić A, Mirt M, Simić V, Simčič T, Paunović M. 2018. The longitudinal pattern of crustacean (Peracarida, Malacostraca) assemblages in a large south European river: bank reinforcement structures as stepping stones of invasion. Ann. Limnol. - Int. J. Lim. 54: 15. 